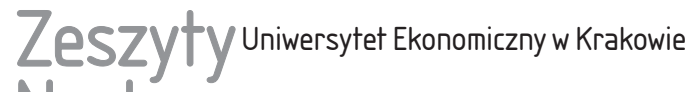 Naukowe
}

$8(932)$

ISSN 1898-6447

Zesz. Nauk. UEK, 2014; 8 (932): 63-77

DOI: 10.15678/ZNUEK.2014.0932.0805

\author{
Joanna Niżnik \\ Katedra Finansów \\ Uniwersytet Ekonomiczny w Krakowie
}

\section{Wpływ kryzysu finansowego na politykę podatkową Republiki Irlandii}

\section{Streszczenie}

Celem artykułu jest przedstawienie i ocena działań prowadzonych przez rząd Irlandii dotyczących zmian w systemie podatkowym i ich wpływu na kształtowanie się dochodów podatkowych. Scharakteryzowano system podatków centralnych Irlandii w latach 2003-2014, wskazano podstawowe elementy ich konstrukcji oraz uwzględniono modyfikacje przeprowadzone na skutek kryzysu. Pokazano, że rząd Irlandii wprowadził istotne zmiany jedynie w podatku dochodowym od osób fizycznych i podatkach kapitałowych, podnosząc stawki podatkowe, obniżając i znosząc ulgi podatkowe czy też wprowadzając nowe obciążenia w postaci podatku od instytucji finansowych i podatku od bogactwa. Działania władz publicznych należy uznać za racjonalne, bowiem podatek od dochodów osób fizycznych jest w Irlandii najbardziej wydajnym źródłem dochodów podatkowych i wprowadzone modyfikacje wpłynęły na wzrost wpływów z tego tytułu, a tym samym dochodów podatkowych ogółem.

Słowa kluczowe: system podatkowy Irlandii, podatki centralne, dochody podatkowe Irlandii, kryzys finansowy.

\section{Wprowadzenie}

Pierwsze przejawy kryzysu finansowego lat 2007-2009 można było zaobserwować w Irlandii w 2008 r. na rynku nieruchomości i kredytów hipotecznych. Bardzo szybko problemy na rynku subprime przeniosły się na cały system 
bankowy [Rosińska-Bukowska 2012, s. 351-352]. Rząd został zmuszony do ratowania upadających banków - koszty tych działań przewyższyły możliwości finansowe państwa, co skutkowało zaciągnięciem zobowiązań w wysokości 67,5 mld euro w Unii Europejskiej i Międzynarodowym Funduszu Walutowym [Whelan 2013, s. 17]. Jednym z narzędzi stabilizujących sytuację gospodarczą kraju stały się podatki.

Celem artykułu jest analiza zmian w systemie podatkowym oraz w dochodach podatkowych Irlandii, które należy wiązać z działaniami rządu podjętymi w reakcji na kryzys. Badaniami objęto lata 2003-2012, natomiast w częściach opracowania dotyczących podatków wykorzystano również dostępne dane z lat 2013-2014.

\section{Uwarunkowania makroekonomiczne}

Punktem wyjścia rozważań jest analiza zmian kształtowania się dynamiki produktu krajowego brutto Irlandii w ujęciu realnym w latach 2003-2012 przedstawionych w tabeli 1. Przeciętne roczne tempo wzrostu PKB wyniosło 1,7\%; najwyższą, wynoszącą 6,1\% dynamikę wzrostu PKB osiągnął w 2005 r., natomiast największy spadek PKB w wysokości 6,4\% wystąpił w 2009 r. Ujemna dynamika wzrostu PKB charakteryzowała Irlandię w latach 2008 i 2010.

Zharmonizowany wskaźnik cen konsumpcyjnych (HICP) w badanym okresie podlegał nieustającym fluktuacjom i mieścił się w przedziale od $-1,7 \%$ do $4 \%$. Zróżnicowanie poziomu inflacji wyniosło zatem 5,7 pkt proc. Średnia inflacja dla tych lat to $1,7 \%$.

Sytuacja gospodarcza ma niewątpliwy wpływ na rynek pracy. Przeciętny wskaźnik bezrobocia dla lat 2003-2012 ukształtował się na poziomie 8,4\%, najwyższy jego wzrost miał miejsce pomiędzy 2008 r. a 2009 r. i wyniósł 5,6 pkt proc. Pomiędzy rokiem 2003 a 2012 stopa bezrobocia zwiększyła się o 10,1 pkt proc.

Tabela 1. Wybrane wskaźniki makroekonomiczne w Irlandii w latach 2003-2012 (\%)

\begin{tabular}{|l|c|c|c|c|c|c|c|c|c|c|}
\hline \multicolumn{1}{|c|}{ Wskaźniki } & 2003 & 2004 & 2005 & 2006 & 2007 & 2008 & 2009 & 2010 & 2011 & 2012 \\
\hline $\begin{array}{l}\text { Realna zmiana } \\
\text { dynamiki PKB }\end{array}$ & 3,7 & 4.2 & 6,1 & 5,5 & 5,0 & $-2,2$ & $-6,4$ & $-1,1$ & 2,2 & 0,2 \\
\hline Inflacja HICP & 4,0 & 2,3 & 2,2 & 2,7 & 2,9 & 3,1 & $-1,7$ & $-1,6$ & 1,2 & 1,9 \\
\hline Stopa bezrobocia & 4,6 & 4,5 & 4,4 & 4,5 & 4,7 & 6,4 & 12,0 & 13,9 & 14,7 & 14,7 \\
\hline
\end{tabular}

Źródło: Eurostat, ec.europa.eu/eurostat/data/database, dostęp: 15.04.2014. 


\begin{tabular}{|c|c|c|c|c|c|}
\hline$\stackrel{\stackrel{\sim}{*}}{\stackrel{\sim}{N}}$ & 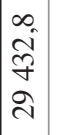 & $\begin{array}{l}n \\
\mathfrak{n} \\
n \\
2\end{array}$ & 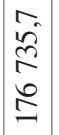 & $\begin{array}{l}\hat{2} \\
\delta \\
2 \\
0 \\
\tilde{2}\end{array}$ & $\begin{array}{l}\frac{m}{2} \\
\frac{\mathfrak{f}}{2} \\
\hat{m}\end{array}$ \\
\hline $\overrightarrow{\bar{d}}$ & 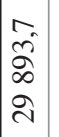 & $\begin{array}{l}0 \\
2 \\
\infty \\
0 \\
0\end{array}$ & 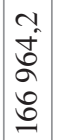 & $\begin{array}{l}0 \\
2 \\
\infty \\
\infty \\
\tilde{m}\end{array}$ & $\begin{array}{l}0 \\
\underset{d}{ \pm} \\
i\end{array}$ \\
\hline$\stackrel{\circ}{\stackrel{ }{\circ}}$ & 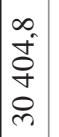 & 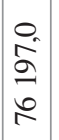 & $\begin{array}{l}0 \\
\infty \\
n \\
n\end{array}$ & $\begin{array}{l}a \\
\tilde{n} \\
\tilde{n} \\
\infty \\
\tilde{c}\end{array}$ & $\begin{array}{l}\overrightarrow{+} \\
\text { +े } \\
\text { वे } \\
\text { वे }\end{array}$ \\
\hline ஜे & 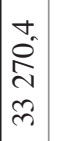 & $\begin{array}{l}= \\
\vec{n} \\
i \\
\hat{n}\end{array}$ & $\begin{array}{l}\hat{\sigma} \\
0 \\
0 \\
0 \\
\pm\end{array}$ & $\begin{array}{l}\sigma \\
\tilde{n} \\
\tilde{n} \\
0 \\
ٍ\end{array}$ & 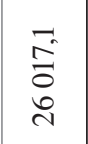 \\
\hline$\stackrel{\infty}{\circ}$ & 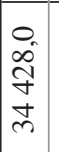 & $\begin{array}{l}0 \\
0 \\
\overline{0} \\
\infty \\
\infty \\
\infty\end{array}$ & $\begin{array}{l}a \\
0 \\
\infty \\
0 \\
0 \\
n \\
1\end{array}$ & $\begin{array}{l}\vec{N} \\
\hat{\infty} \\
m \\
\ddot{z}\end{array}$ & 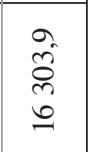 \\
\hline 홍 & $\begin{array}{l}n \\
n \\
\tilde{n} \\
\tilde{n} \\
n\end{array}$ & $\begin{array}{l}+ \\
\infty \\
\curvearrowright \\
\sim \\
\infty\end{array}$ & $\begin{array}{l}2 \\
\infty \\
\tilde{n} \\
\tilde{n}\end{array}$ & $\begin{array}{l}\infty \\
\tilde{n} \\
\tilde{n} \\
\tilde{n} \\
\end{array}$ & 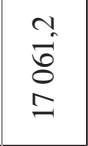 \\
\hline ஜ̊ & 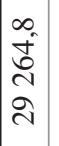 & 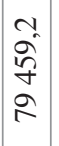 & 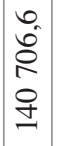 & $\begin{array}{l}\infty \\
\tilde{\Omega} \\
\tilde{n} \\
\tilde{\Omega}\end{array}$ & $\begin{array}{l}\infty \\
\stackrel{1}{ } \\
\stackrel{2}{I}\end{array}$ \\
\hline$\stackrel{n}{8}$ & $\begin{array}{l}\tilde{z} \\
\tilde{N} \\
\tilde{n} \\
\check{v}\end{array}$ & $\begin{array}{l}\Omega \\
\tilde{n} \\
\stackrel{n}{N} \\
N\end{array}$ & 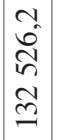 & $\begin{array}{l}\tilde{n} \\
\dddot{\sigma} \\
=\end{array}$ & 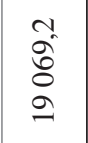 \\
\hline ষ্ণ & 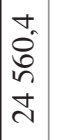 & $\begin{array}{l}2 \\
2 \\
2 \\
0 \\
0\end{array}$ & $\begin{array}{l}0 \\
\infty \\
2 \\
\tilde{a} \\
\tilde{I}\end{array}$ & $\begin{array}{l}\sigma_{j} \\
\tilde{N} \\
\infty \\
\tilde{O} \\
\tilde{O}\end{array}$ & 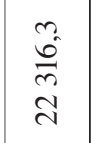 \\
\hline ֻ̊ి & $\begin{array}{l}a \\
\hat{a} \\
\mathfrak{d} \\
\mathfrak{d}\end{array}$ & $\begin{array}{c}0 \\
\tilde{y} \\
f \\
\text { ช̂ }\end{array}$ & $\begin{array}{l}\Xi \\
\equiv \\
\equiv\end{array}$ & $\begin{array}{l}\infty \\
8 \\
8 \\
\dot{\sigma} \\
\dot{0}\end{array}$ & $\begin{array}{l}\stackrel{\vartheta}{2} \\
\stackrel{+}{+} \\
\text { ปे }\end{array}$ \\
\hline 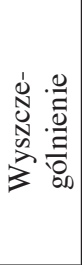 & 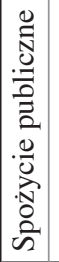 & 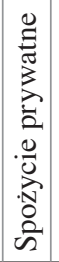 & 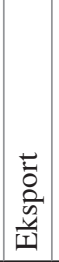 & 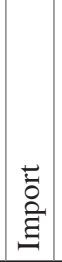 & 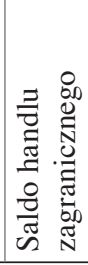 \\
\hline
\end{tabular}


Na poziom produktu krajowego brutto wpływa m.in. spożycie krajowe. Na podstawie danych zawartych w tabeli 2 można zauważyć, że krajowy popyt finalny pomiędzy rokiem 2003 a 2014 zwiększył się o ok. 23\%. Znaczący wpływ na ukształtowanie się tej wielkości miały dynamiki cząstkowe popytu publicznego i prywatnego. Popyt zgłaszany przez państwo zwiększał się corocznie w całym badanym okresie o ok. 29,7\%. Nie on jednak miał decydujący wpływ na zmiany w zakresie spożycia finalnego, bowiem to popyt zgłaszany przez gospodarstwa domowe w całym badanym okresie stanowił ok. $72,4 \%$, a średnioroczne tempo wzrostu spożycia indywidualnego wynosiło ok. 20,6\%.

Odziaływanie popytu zagranicznego na produkt krajowy brutto najlepiej obrazowane jest kształtowaniem się salda obrotów zagranicznych. $Z$ danych przedstawionych w tabeli 2 wynika, że w Irlandii w całym badanym okresie wyniki bilansu płatniczego były dodatnie. Pomiędzy rokiem 2003 a 2012 dynamika salda obrotów zagranicznych wyniosła $176 \%$, na co złożył się wzrost eksportu o 50,8\% i importu o $44,6 \%$.

Przyjmując za punkt wyjścia rozważań rok 2008, który dzieli okres 2003-2012 na dwie równe części, można zauważyć następujące skutki kryzysu finansowego. Dynamika realnego produktu krajowego brutto spadła o 6,4 pkt proc., a poziom PKB obniżył się z przeciętnych 6,4\% dla lat 2003-2007 do ujemnego w wysokości 1,5\% w latach 2008-2012. Tempo wzrostu popytu publicznego zmniejszyło się o 6,8 pkt proc., zaś w pięciu ostatnich latach zanotowano jego spadek średnio o 2,5 pkt proc. Podobnie kształtowały się tendencje dotyczące spożycia prywatnego, obniżyło się ono bowiem o 6,7 pkt proc. Kluczową rolę w rozwoju gospodarczym Irlandii odgrywa handel zagraniczny - we wszystkich badanych latach odnotowano dodatnie saldo obrotów handlowych. Jednakże tempo zmian eksportu i importu było zdecydowanie niższe, odpowiednio o 3,5 i 8,5 pkt proc. W konsekwencji spowolnienie wpłynęło niekorzystnie na rynek pracy, co najpełniej obrazuje 2,7-krotny wzrost stopy bezrobocia.

\section{Zmiany systemu podatkowego Irlandii w latach 2003-2012}

\subsection{Podatek dochodowy od osób fizycznych}

Podatek dochodowy od osób fizycznych został wprowadzony w 1997 r. ustawą o konsolidacji podatków (Tax Consolidation Act). Wpływy z podatku stanowią dochód władz centralnych. Podatnikami są rezydenci i osoby niebędące rezydentami, ale uzyskujące dochód ze źródeł położonych na terytorium Irlandii. Rezydentami są osoby przebywające na terytorium Irlandii w roku podatkowym powyżej 183 dni lub w ciągu dwóch następujących kolejno po sobie lat przez okres dłuższy niż 280 dni. 
Tabela 3. Stopy podatkowe i progi podatkowe PIT w Irlandii w latach 2003-2014

\begin{tabular}{|c|c|c|c|c|c|}
\hline \multirow{2}{*}{ Rok } & \multirow{2}{*}{$\begin{array}{c}\text { Stopa } \\
\%\end{array}$} & $\begin{array}{c}\text { osoba samotna } \\
\text { bezdzietna }\end{array}$ & $\begin{array}{c}\text { Psoba samotna } \\
\text { z dzieckiem }\end{array}$ & $\begin{array}{c}\text { małżeństwo } \\
\text { z jednym } \\
\text { dochodem }\end{array}$ & $\begin{array}{c}\text { małżeństwo } \\
\text { z dwoma } \\
\text { dochodami }\end{array}$ \\
\cline { 3 - 6 } & $2003-$ & 32000 & 37000 & $\begin{array}{c}56000 \\
(19000)\end{array}$ \\
\hline 2004 & 20,42 & 28000 & 33400 & 38400 & $\begin{array}{c}58800 \\
(20400)\end{array}$ \\
\hline 2006 & 20,42 & 29400 & 36000 & 41000 & $\begin{array}{c}64000 \\
(23000)\end{array}$ \\
\hline 2007 & 20,41 & 34000 & 38000 & 43000 & $\begin{array}{c}68000 \\
(25000)\end{array}$ \\
\hline 2008 & 20,41 & 35400 & 39400 & 44400 & $\begin{array}{c}70800 \\
(26400)\end{array}$ \\
\hline $\begin{array}{c}2009- \\
2010\end{array}$ & 20,41 & 36400 & 40400 & 45400 & $\begin{array}{c}72800 \\
(27400)\end{array}$ \\
\hline $\begin{array}{c}2011- \\
2014\end{array}$ & 20,41 & 32800 & 36800 & 41800 & $\begin{array}{c}65600 \\
(23800)\end{array}$ \\
\hline
\end{tabular}

Źródło: www.taxworld.ie/taxes/it/2004-2014/summary, dostęp: 15.04.2014.

Na podstawie danych podanych w tabeli 3 można stwierdzić, że w podatku dochodowym od osób fizycznych w Irlandii wysokość obciążenia zależy od sytuacji rodzinnej podatnika. Dochód podlegający opodatkowaniu według stopy standardowej zmienia się w zależności od tego, czy rozliczenie jest indywidualne czy wspólne.

Widoczne są pewne prawidłowości w określaniu wysokości progów podatkowych dla poszczególnych kategorii podatników. Jeżeli za punkt odniesienia przyjmiemy podlegające opodatkowaniu dochody osoby rozliczającej się samodzielnie i bezdzietnej, to w całym badanym okresie w każdym z lat maksymalna kwota dochodu obciążonego stopą najniższą dla osoby samotnie wychowującej dziecko była od tej wielkości o 4000 euro wyższa, dla małżeństwa mającego jeden dochód i rozliczającego się wspólnie przewyższała ten próg o 9000 euro, dla małżeństwa uzyskującego dochody przez każdego z małżonków i łączącego je w rocznym rozliczeniu stanowiła jej dwukrotność. Poza tym corocznie zwiększano podstawy opodatkowania przeciętnie o ok. 5\%, z wyjątkiem 2011 r. kiedy obniżono je w stosunku do poprzedniego roku o ok. 10\% i zamrożono.

W latach 2003-2014 obowiązywały tylko dwie stopy podatkowe PIT. Do 2006 r. stopa krańcowa wynosiła 42\%. Kryzys finansowy lat 2007-2009 spowodował jej niewielkie obniżenie do poziomu $41 \%$. 
Tabela 4. Dochód niepodlegający opodatkowaniu PIT w Irlandii w latach 2003-2014 (euro)

\begin{tabular}{|l|c|c|c|c|c|c|}
\hline \multicolumn{1}{|c|}{ Osoba samotna } & $2003-2004$ & 2005 & 2006 & 2007 & $2008-2010$ & 2011-2014 \\
\hline $\begin{array}{l}\text { Osoba, która } \\
\text { nie ukończyła } \\
\text { 65. roku życia }\end{array}$ & 5210 & 5210 & 5210 & 5210 & - & - \\
\hline $\begin{array}{l}\text { Osoba, która } \\
\text { ukończyła } \\
\text { 65. rok życia }\end{array}$ & 1550 & 16500 & 17000 & 19000 & 20000 & 18000 \\
\hline
\end{tabular}

Źródło: opracowanie własne na podstawie: http://www.revenue.ie/en/tax/it/leaflets/it1.html, www.taxworld.ie/taxes/it, dostęp: 15.04.2014.

Opodatkowaniu podatkiem dochodowym od osób fizycznych podlegają dochody przewyższające kwoty podane w tabeli 4. W latach 2003-2014 wszystkie osoby uzyskujące dochody mogły skorzystać z tej ulgi. Sytuacja zmieniła się w 2008 r. i obecnie osoby, które nie ukończyły 65. roku życia, opodatkowują dochody w pełnej wysokości. Jeżeli rozlicza się małżeństwo, kwoty dochodów zwolnionych z opodatkowania zwiększane są dwukrotnie. Dodatkowo w całym analizowanym okresie na każde pierwsze lub drugie dziecko podatnicy mogą podnieść dochód wolny od podatku o 575 euro, a na trzecie i kolejne o 830 euro.

Tabela 5. Wybrane odliczenia od podatku w PIT w Irlandii w latach 2003-2014 (euro)

\begin{tabular}{|l|c|c|c|c|c|c|}
\hline \multicolumn{1}{|c|}{ Wyszczególnienie } & $\begin{array}{c}2003- \\
2004\end{array}$ & 2005 & 2006 & 2007 & $\begin{array}{c}2008- \\
2010\end{array}$ & $\begin{array}{c}2011- \\
2014\end{array}$ \\
\hline Osoba samotna & 1520 & 1580 & 1630 & 1760 & 1830 & 1650 \\
\hline $\begin{array}{l}\text { Małżeństwo/osoba samotnie } \\
\text { wychowująca dziecko }\end{array}$ & 3040 & 3160 & 3260 & 3520 & 3660 & 3300 \\
\hline $\begin{array}{l}\text { Bezdzietna wdowa } \\
\text { lub wdowiec }\end{array}$ & 1820 & 1980 & 2130 & 2310 & 2430 & 2190 \\
\hline Zasiłek pielęgnacyjny & 500 & 1000 & 1500 & 3000 & 3660 & 3300 \\
\hline Zasiłek starczy $^{\mathrm{b}}$ & 205,410 & 205,410 & 250,500 & 275,550 & 325,650 & 245,490 \\
\hline
\end{tabular}

${ }^{a}$ również wdowa lub wdowiec, ${ }^{\text {b }}$ osoby, które ukończyły 65 . rok życia; pierwsza wartość dotyczy osób samotnych, druga - małżeństw.

Źródło: opracowanie własne na podstawie: http://www.revenue.ie/en/tax/it/leaflets/it1.html, www.taxworld.ie/taxes/it, dostęp: 15.04.2014.

Dane podane w tabeli 5 wskazują, że podatnicy mogą korzystać z wielu ulg od podatku, których wysokość związana jest z ich indywidualnymi cechami. Rok 
2011 przyniósł obniżenie wysokości wszystkich odliczeń od podatku przeciętnie o ok. $10 \%$, w przypadku zasiłku starczego o ok. $2,5 \%$.

\subsection{Podatek dochodowy od osób prawnych}

Podatek dochodowy od osób prawnych funkcjonuje według zasad określonych w 1997 r. ustawą o konsolidacji podatków (Tax Consolidation Act). Podmiotami opodatkowania są jednostki posiadające status rezydentów lub nierezydenci uzyskujący dochody poprzez oddziały i agencje mające siedzibę na terytorium Irlandii z tytułu generowanych dochodów i zysków kapitałowych pochodzących z posiadanych nieruchomości, praw do wydobycia kopalin i używanych w działalności gospodarczej aktywów. W przypadku poniesienia straty z działalności gospodarczej można w ciągu roku podatkowego obniżyć o jej wielkość każdy dochód osiągnięty z pozostałej działalności lub rozliczyć ją w następnym roku. O kwoty strat z innych tytułów można pomniejszyć tylko zyski z tych samych źródeł w bieżącym okresie bądź w następnych latach aż do ich całkowitego rozliczenia.

Standardowa stopa podatkowa przez wszystkie badane lata wynosiła $12,5 \%$ [Steward 2014, s. 7] i była stosowana do wszystkich podmiotów gospodarczych niezależnie od branży [Balza 2013, s. 152]. Wyższą, 25-proc. stopą podatkową są obciążane dochody pochodzące z nieopodatkowanych zysków i dochodów z nieruchomości położonych za granicą, dochodów z wynajmu nieruchomości, dochodów z działalności górniczej i związanej z paliwami oraz gruntów.

Szczególne regulacje dotyczą start-upów rozpoczynających działalność gospodarczą pomiędzy rokiem 2009 a 2014, które mają prawo do ulgi od podatku w wysokości 40000 euro rocznie przez trzy lata. Aby skorzystać z odliczenia, osoba prawna powinna opłacać składki na ubezpieczenia społeczne za pracowników nie wyższe niż 5000 euro liczone na pracownika, a ich łączna kwota nie powinna przekroczyć 40000 euro rocznie.

\subsection{Podatek od wartości dodanej oraz podatek akcyzowy}

Podatek od wartości dodanej (VAT) został wprowadzony 1 listopada 1972 r. i od tego czasu podlegał wielu modyfikacjom. Ze zwolnienia podmiotowego mają prawo skorzystać podatnicy, których wielkość przychodów ze sprzedaży nie przekroczyła określonej prawem wysokości ustalanej ze względu na rodzaj prowadzonej działalności. Dla osób prowadzących działalność usługową jest to 37500 euro, dla dostarczających towary 70000 euro, dla prowadzących sprzedaż na odległość (internetową lub katalogową) 35000 euro, a dla dokonujących wewnątrzwspólnotowej dostawy towarów lub nabycia towarów 41000 euro. Obowiązek rejestracyjny w zakresie podatku od towarów i usług powstaje w momencie, kiedy obrót zbliża się do wyznaczonej prawem granicy lub można 
go dopełnić w chwili rozpoczęcia działalności gospodarczej. Jeżeli wielkość przychodów ze sprzedaży w danym roku nie przekracza ustalonych ustawowych granic, można się wyrejestrować. Za niedopełnienie obowiązku rejestracyjnego grozi kara w wysokości 4000 euro [Worldwide VAT... 2013, s. 351-353].

Rozliczenia VAT mają miejsce w okresach dwumiesięcznych na zasadach memoriałowych. Podmioty gospodarcze otrzymujące zwrot VAT mogą rozliczać się miesięcznie. Podatnicy podatku od wartości dodanej, którzy sprzedają swoje towary i usługi wyłącznie osobom niebędącym podatnikami VAT (co najmniej 90\% obrotu) lub których roczne przychody ze sprzedaży nie przekraczają 1 mln euro (od 1 maja 2013 r. 1,25 mln euro), mogą zwrócić się do organu skarbowego z prośbą o rozliczanie na zasadzie kasowej [Worldwide VAT... 2013, s. 360].

Modyfikacje w zakresie ustawodawstwa dotyczącego VAT polegały głównie na zmianach wysokości stawek podatkowych, jak również zakresu opodatkowania. Od 1 stycznia 2003 r. do 30 listopada 2008 r. podstawowa stawka VAT wynosiła $21 \%$, następnie od 1 grudnia 2008 r. do końca 2009 r. podwyższono ją do 21,5\%, by od 1 stycznia 2010 r. do 31 grudnia 2011 r. powrócić do wcześniejszej 21-proc. stopy. Od początku 2012 r. obowiązuje nowa, podwyższona do 23\% stawka.

Tabela 6. Stawki VAT w Irlandii w latach 2003-2014 (\%)

\begin{tabular}{|c|c|c|c|c|}
\hline Lata & $\begin{array}{c}\text { Stawka } \\
\text { podstawowa }\end{array}$ & $\begin{array}{c}\text { Stawka } \\
\text { pośrednia }\end{array}$ & $\begin{array}{c}\text { Stawka } \\
\text { zredukowana 1 }\end{array}$ & $\begin{array}{c}\text { Stawka } \\
\text { zredukowana 2 }\end{array}$ \\
\hline 2003 & 21 & 13,5 & 4,3 & - \\
\hline 2004 & 21 & 13,5 & 4,4 & - \\
\hline $2005-2008$ & 21 & 13,5 & 4,8 & - \\
\hline $2008-2009$ & 21,5 & 13,5 & 4,8 & - \\
\hline $2010-2011$ & 21 & 13,5 & 4,8 & 9 \\
\hline 2011 & 21 & 13,5 & 4,8 & 9 \\
\hline $2012-2014$ & 23 & 13,5 & 4,8 & \\
\hline
\end{tabular}

Źródło: [VAT Rates... 2014, s. 25-26].

W Irlandii oprócz stawki podstawowej funkcjonują stopy preferencyjne. W całym analizowanym okresie stawka pośrednia wynosiła $13,5 \%$ i stosuje się ją do energii zużywanej dla celów ogrzewania i dostarczania światła, usług w zakresie remontów, sprzątania i utrzymania nieruchomości, usług dotyczących chirurgii zwierząt, szkół jazdy, usług fotograficznych i niektórych usług turystycznych, jak również wyrobów artystycznych i dzieł sztuki [Leahy, Lions i Tol 2011, s. 214].

Najniższą stawką w wysokości 4,8\% opodatkowano: żywność, żywy inwentarz, hodowlę chartów. Przez cały 2003 r. i 2004 r. była ona niższa, a jej wysokość 
kształtowała się na poziomie odpowiednio 4,3\% i 4,4\%. Obowiązującą od 1 lipca 2011 r. stawką w wysokości $9 \%$ objęto następujące produkty i usługi: gazety i czasopisma oraz usługi hotelowe, restauracyjne, cateringowe i fryzjerskie [VAT Rates... 2014, s. 4-26].

Zwolnione od podatku VAT są usługi medyczne, pocztowe, finansowe, ubezpieczeniowe, leasing nieruchomości. Stawką zerową objęto: książki, żywność niskoprzetworzoną, ubrania i buty dla dzieci poniżej 10. roku życia, usługi stomatologiczne, usługi transportu osób, eksport.

Podatek akcyzowy zaczął obowiązywać od 1 stycznia 1997 r. ${ }^{1}$ Opodatkowaniu podlegają oleje mineralne (włącznie z benzyną i olejem napędowym), produkty alkoholowe (spirytus, piwo, wino, cydr oraz alkohole powstające z gruszek) oraz wyroby tytoniowe. Obciążone podatkiem są również elektryczność, zakłady bukmacherskie oraz pierwsza rejestracja samochodu w Irlandii (podatek od rejestracji pojazdów - vehicle registration tax). Czynnikami wpływającymi na wysokość podatku od rejestracji pojazdów są emisja dwutlenku węgla oraz rynkowa cena samochodu [Ireland Taxation... 2014; Hennessy i Tol 2011, s. 7059-7067].

\subsection{Pozostałe podatki centralne}

Podatek od odsetek (deposit interest retention tax) funkcjonujący od $2002 \mathrm{r}$. nakładany jest na dochody odsetkowe z tytułu posiadania depozytów w instytucjach finansowych takich jak banki, towarzystwa budowlane czy poczta. Opłacany jest przez te podmioty w imieniu posiadacza konta w momencie naliczenia dochodu.

Osoby powyżej 65. roku życia oraz osoby ze stwierdzoną niepełnosprawnością mają prawo do zwrotu zapłaconego podatku od odsetek bądź ubieganie się o jego niepłacenie. Aby możliwe było skorzystanie z tych uprawnień, dochód takiej osoby łącznie z dochodem małżonka nie może przekroczyć dochodu niepodlegającego opodatkowaniu lub zobowiązanie podatkowe takiej osoby powinno być niższe od łącznej kwoty odliczeń podatkowych, z których korzysta ${ }^{2}$.

Tabela 7. Stopy podatku od odsetek w Irlandii w latach 2003-2014 (\%)

\begin{tabular}{|c|c|c|c|c|c|c|}
\hline $2003-2008$ & 2009 & $2009-2010$ & 2011 & 2012 & 2013 & 2014 \\
\hline 20 & 23 & 25 & 27 & 30 & 33 & 41 \\
\hline
\end{tabular}

Źródło: http://www.revenue.ie/en/tax/dirt/index.html, dostęp: 15.04.2014.

\footnotetext{
${ }^{1}$ http://ec.europa.eu/taxation_customs/tedb/taxDetails.html, dostęp: 12.04.2014.

2 http://www.citizensinformation.ie/en/money_and_tax/tax/tax_on_savings_and_investments/ deposit_interest_retention_tax.html, dostęp: 12.04.2014.
} 
W całym badanym okresie 2003-2014 zmiany stawek podatku od odsetek odbywały się z początkiem roku z wyjątkiem 2009 r., kiedy to od 8 kwietnia zaczęła obowiązywać nowa stopa ${ }^{3}$. Pomiędzy rokiem 2003 a 2014 stopa podatkowa powiększyła się przeszło dwukrotnie, największy wzrost miał miejsce w ostatnim roku, kiedy to stawkę podatku od odsetek podniesiono o 8 pkt proc.

Ustawa finansowa z 2013 r. nałożyła nowy podatek na instytucje finansowe (levy on financial institutions) takie jak banki i towarzystwa budowlane prowadzące działalność na terytorium Irlandii, których właścicielami są Irlandczycy lub podmioty europejskie. Podatek obowiązuje od 2014 r. do 2016 r. Jego wysokość jest równa 35\% kwoty podatku od depozytów, jaką odprowadziły w $2011 \mathrm{r}$. w imieniu swoich klientów instytucje finansowe. Zwolnione od podatku są podmioty, których zobowiązanie z tytułu podatku od odsetek w 2011 r. nie przekroczyło 100000 euro.

Podatek od zysków z oszczędności (exit tax) wprowadzony w życie 1 stycznia 2001 r. nakładany jest na dochody uzyskiwane z planów oszczędnościowych, ubezpieczeń na życie i dożycie oraz z obligacji inwestycyjnych.

Tabela 8. Stopy podatku od zysków z oszczędności w Irlandii w latach 2003-2014 (\%)

\begin{tabular}{|c|c|c|c|c|c|c|}
\hline $2003-2008$ & 2009 & $2009-2010$ & 2011 & 2012 & 2013 & 2014 \\
\hline 23 & 26 & 28 & 30 & 33 & 36 & 41 \\
\hline
\end{tabular}

Źródło: http://www.bline.ie/uploadedFiles/bline/Protection/Protection_Library/exit_tax.pdf, dostęp: 13.04.2014.

W analizowanym okresie 2003-2014 stawki podatku zmieniano 1 stycznia. Pod tym względem 2009 r. były wyjątkowy, 8 kwietnia bowiem podniesiono stawkę podatkową z poziomu $26 \%$ do $28 \%$. Pomiędzy rokiem 2003 a 2014 stopa podatku wzrosła o 14 pkt proc.

Podatek od dochodów kapitałowych (capital gains tax) to podatek od dochodów uzyskiwanych z posiadanych aktywów (m.in. papiery wartościowe, goodwill, opcje na aktywa, nieruchomości). Podstawę opodatkowania stanowi różnica pomiędzy wartością zakupu a wartością sprzedaży aktywów. W przypadku zakupu nieruchomości przed końcem 2014 r. i posiadania jej przez okres dłuższy niż 7 lat dochody z jej sprzedaży nie podlegają opodatkowaniu.

Od 2003 r. do 14 października 2008 r. stopa podatkowa wynosiła 20\%, następnie do 7 kwietnia 2009 r. była równa 22\%, do 6 grudnia 2011 r. wynosiła $25 \%$, do 5 grudnia 2012 r. 30\%, a od tej daty osiągnęła poziom $33 \%$.

\footnotetext{
${ }^{3}$ http://www.revenue.ie/en/tax/dirt/index.html, dostęp 12.04.2014.
} 
Tabela 9. Stopy podatku od dochodów kapitałowych w Irlandii w latach 2003-2014 (\%)

\begin{tabular}{|c|c|c|c|c|}
\hline $2003-2008$ & $2008-2009$ & $2009-2011$ & $2011-12$ & $2012-2014$ \\
\hline 20 & 22 & 25 & 30 & 33 \\
\hline
\end{tabular}

Źródło: http://www.citizensinformation.ie/en/money_and_tax/tax/capital_taxes/capital_gains_tax. html, dostęp: 13.04.2014.

Podatek od bogactwa (domicil levy) wprowadzony 1 stycznia 2010 r. jest nakładany na osoby fizyczne mające obywatelstwo lub miejsce zamieszkania na terytorium Irlandii, których aktywa przekraczają $1 \mathrm{mln}$ euro, wartość ich nieruchomości położonych w Irlandii jest wyższa niż $5 \mathrm{mln}$ euro, a wartość rocznego zobowiązania podatkowego $\mathrm{z}$ tytułu podatku dochodowego nie przekracza 200000 euro. Wartość obciążenia podatkowego z tytułu podatku od bogactwa wynosi 200000 euro $^{4}$.

\section{Zmiany wielkości i struktury dochodów podatkowych}

Dane zawarte w tabeli 10 dotyczące wielkości dochodów podatkowych Irlandii pozwalają dostrzec zmienność dochodów w zakresie zarówno ich dynamiki, tempa wzrostu, jak i nominalnych wartości. W latach 2003-2007 dochody podatkowe rosły nierównomiernie średnio o $10 \%$ rok do roku, by przez następne trzy lata obniżać się o 11\% rocznie i w latach 2011-2012 przyrastać o ok. 6\%. Jeżeli za punkt wyjścia przyjmiemy rok 2003 r. i porównamy dynamikę poszczególnych wpływów podatkowych do tego roku, można zauważyć, że najszybciej dochody podatkowe rosły w 2007 r. - przeciętnie o 147\%, a najmniejszą, 103-proc. dynamiką charakteryzowały się podatki w 2010 r. Stąd najwyższą nominalną wartość wpływy podatkowe osiągnęły w 2007 r., przynosząc państwu dochody w wysokości 49 764,9 mln euro i przewyższając tym samym najniższe dochody uzyskane w 2003 r. w wysokości 33 926,9 mln euro o $15838 \mathrm{mln}$ euro, czyli o ok. 46,7\%.

W strukturze wpływów podatkowych najważniejsze miejsce zajmują podatki od produkcji i importu, a ich przeciętny udział w całości dochodów podatkowych w latach 2003-2012 wyniósł ok. 50,2\%. Uzupełnieniem wpływów podatkowych były podatki od dochodów i majątku, które stanowiły 48,8\% wpływów. Przeciętny udział dochodów z podatków od kapitału w latach 2003-2012 nie przekroczył 1\%. Pozycja podatków od dochodów i majątku rośnie. Od początku analizowanego okresu do 2010 r. wpływy z tego tytułu wynosiły ok. 48\% całości dochodów, by w dwóch ostatnich latach ukształtować się na poziomie ok. 52\%. Natomiast udział podatków od produkcji i importu w strukturze dochodów ogółem obniżył

\footnotetext{
${ }^{4}$ http://www.payeanytime.ie/en/tax/domicile-levy/index.html, dostęp: 12.04.2014.
} 

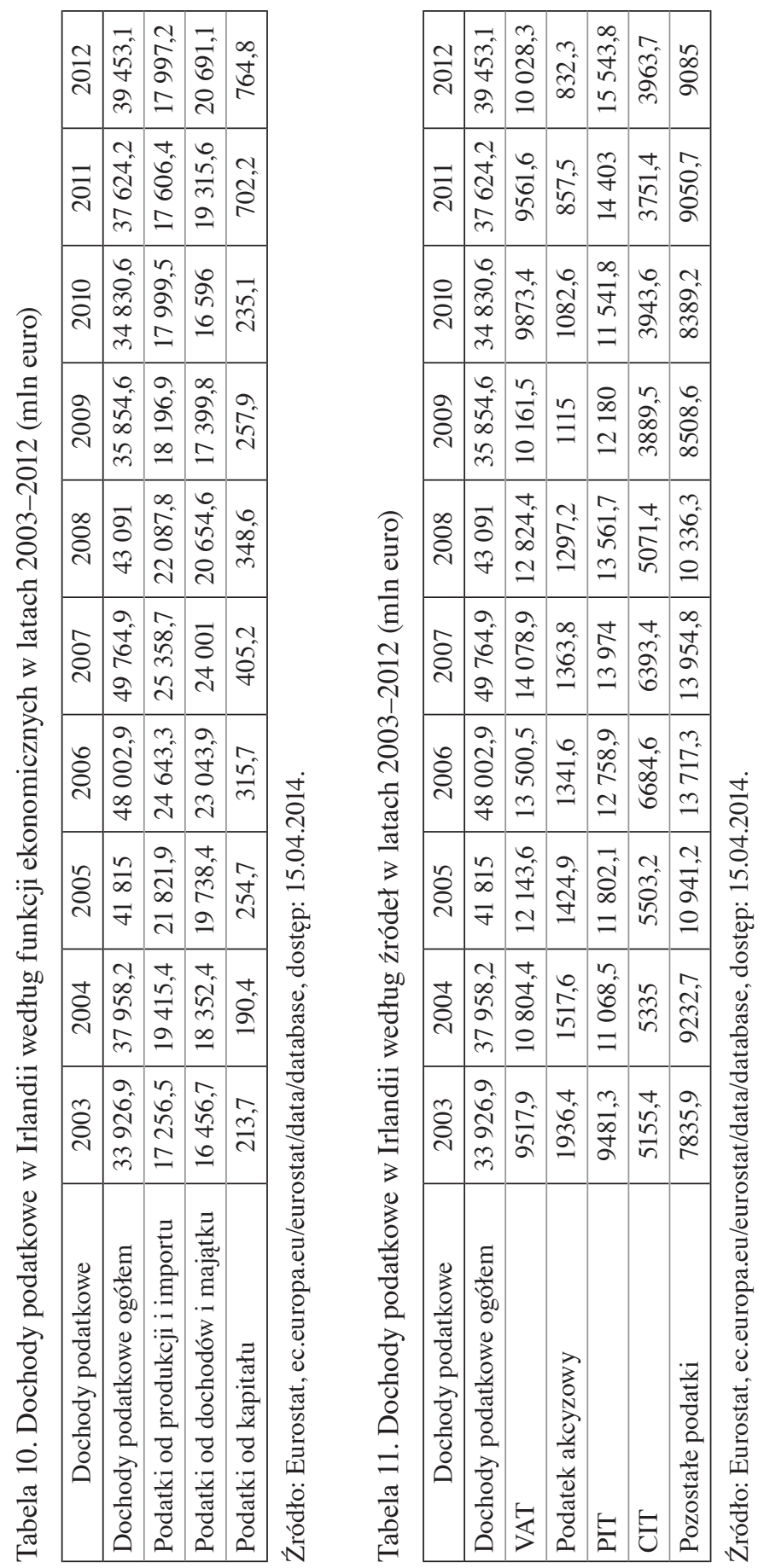
się w tym samym okresie o 4 pkt proc. do ok. 46\%. Zmiany legislacyjne spowodowały dwukrotny wzrost udziału dochodów z kapitałów do poziomu $2 \%$ całości dochodów.

Dochody podatkowe można analizować w sposób bardziej szczegółowy, biorąc pod uwagę podstawowe ich kategorie wyróżnione przy okazji omawiania zagadnień związanych z przeobrażeniami systemu podatkowego Irlandii ukazane w tabeli 11. Największe dochody podatkowe sektor general government uzyskiwał w latach 2003-2012 z tytułu podatku dochodowego od osób fizycznych, którego przeciętny udział wyniósł 31,6\%. Drugim co do wydajności źródłem dochodów publicznych był podatek od wartości dodanej z udziałem wynoszącym 27,9\%. Podatek dochodowy od osób prawnych oraz podatek akcyzowy stanowiły średnio $12,3 \%$ i 3,2\% całości dochodów. Największą dynamikę liczoną w stosunku do 2003 r. osiągnęły wpływy z podatku dochodowego od osób fizycznych w 2012 r. - wyniosła ona 164\%, najniższą dynamikę wykazały dochody z PIT w 2004 r. - wyniosła ona $117 \%$. W przypadku podatku VAT najszybciej, bo o $147 \%$ w stosunku do roku bazowego, rosły dochody w 2007 r., a najwolniej w 2011 r., kiedy były niewiele wyższe od osiągniętych w 2003 r.

Kryzys finansowy oddziaływał znacząco na kształtowanie się struktury dochodów podatkowych. Jeżeli badany okres 2003-2012 zostanie podzielony na dwie równe części, to od 2008 r. można zauważyć wzrost o 7,3 pkt proc. udziału wpływów z tytułu podatku dochodowego od osób fizycznych w całości dochodów podatkowych - z poziomu $28 \%$ do $35,3 \%$ - natomiast udział podatku dochodowego od osób prawnych w tych samych latach spadł o 3 pkt proc. z poziomu $13,8 \%$ do $10,8 \%$. Udział podatku od wartości dodanej w strukturze dochodów obniżył się w niewielkim zakresie, bo jedynie o 1 pkt proc.

Próbując odpowiedzieć na pytanie, w jaki sposób zmiany w systemie podatkowym wpłynęły na wielkości wpływów podatkowych, należałoby przyjrzeć się bardziej wnikliwie poszczególnym rodzajom podatków. W 2010 r. dokonano znaczących modyfikacji wysokości progów podatkowych oraz ulg podatkowych w podatku dochodowym od osób fizycznych. Wydaje się, że zwiększenie wpływów podatkowych w 2011 r. z tego tytułu o 2861,2 mln euro, czyli o 24,8\%, oraz o 1140,8 mln euro, tj. o 7,9\%, w roku następnym należy łączyć z tymi zmianami. Oddziaływać na wysokość dochodów z PIT mogło też wprowadzenie podatku od bogactwa. W przypadku podatku dochodowego od osób prawnych wprowadzenie zachęt dla start-upów nie miało wpływu na kształtowanie się dochodów podatkowych, podobnie jak wprowadzenie nowej, 9-proc. stawki podatkowej podatku od wartości dodanej. 


\section{Podsumowanie}

Kryzys finansowy wpłynął na pogorszenie sytuacji gospodarczej, jak również na wysokość dochodów podatkowych Irlandii. Potwierdzają tę tezę negatywne zmiany wielkości makroekonomicznych i dane dotyczące wielkości wpływów z poszczególnych podatków.

Reakcja rządu dotycząca zmian w funkcjonującym systemie podatkowym nastąpiła z pewnym opóźnieniem. Od 2009 r. podniesiono stopy podatkowe podatków obciążających kapitały pieniężne i oszczędności (podatek od odsetek, podatek od zysków z oszczędności, podatek od dochodów kapitałowych). Największe zmiany miały miejsce z początkiem 2011 r., kiedy korekcie poddano podatek dochodowy od osób fizycznych, będący podstawowym źródłem dochodów podatkowych, zmniejszając wysokość progów podatkowych oraz ulg podatkowych. W dalszym ciągu podnoszono poziom stóp podatkowych w podatkach od kapitałów. Pozostałe podatki poddano niewielkim modyfikacjom.

Działania prowadzone przez rząd Irlandii wydają się racjonalne, widoczne są bowiem już pierwsze pozytywne rezultaty prowadzonej polityki w postaci wzrostu dochodów podatkowych ogółem, w tym w szczególności w zakresie podatków dochodowych. Jeżeli gospodarka Irlandii wejdzie zdecydowanie na ścieżkę wzrostu gospodarczego, to wprowadzone w czasie kryzysu zmiany w podatkach mogą w sposób mnożnikowy oddziaływać na wpływy podatkowe.

\section{Literatura}

Balza B. [2013], Obciażenia fiskalne przedsiębiorstw a międzynarodowa konkurencyjność gospodarcza, Difin, Warszawa.

Hennessy H., Tol R.S.J. [2011], The Impact of Tax Reform on New Car Purchases in Ireland, „Energy Policy”, vol. 39, iss. 11, http://dx.doi.org/10.1016/j.enpol.2011.08.011.

Ireland taxation system [2014], http://www.commissionontaxation.ie/downloads/ part\%203.pdf, dostęp: 15.04.2014.

Leahy E., Lions S., Tol R.S.J. [2011], The Distributional Effects of Value Added Tax in Ireland, ,The Economic and Social Review”, vol. 42, nr 2.

Rosińska-Bukowska M. [2012], Kryzys w strefie euro - wybrane aspekty makro- i mikroekonomiczne, Acta Universitatis Lodziensis, Folia Oeconomica, nr 273, Łódź.

Steward J. [2014], PwC/World Bank Report 'Paying Taxes 2014': An Assessment, IIIS Discussion Paper No. 442.

Whelan K. [2013], Ireland's Economic Crisis. The Good, the Bad and the Ugly, UCD Centre for Economic Research Working Paper series WP13/06.

Worldwide VAT, GST and Sales Tax Guide [2013], Ernst \& Young.

VAT Rates Applied in the Member States of the European Union [2014], European Commission. 


\section{The Influence of the Financial Crisis on Tax Policy in the Republic of Ireland}

The aim of this paper is to present and evaluate the changes introduced by the Irish government in the tax system and their influence on tax revenues. The first part offers a brief summary of the overall structure of the state tax system, identifying elements of tax construction and the changes caused by the financial crisis. The second part focuses on the major changes in personal income tax and capital taxes, which entailed raising the tax rate, the reduction and abolition of tax relief and the introduction of new taxes, such as a levy on financial institutions and the domicile levy. The other taxes have hardly been modified but their share of, and influence on, tax revenue is less significant.

Keywords: Irish tax system, state taxes, tax revenue in Ireland, financial crisis. 